\title{
Comparative study of the effect of natural planting, hydroponic germination and barley sprout powder as prebiotic in common carp Cyprinus carpio $\mathrm{L}$. blood indices
}

\author{
H.S. Abedalhammed ${ }^{1 *}$, N.M. Abdulrahman ${ }^{2}$ and H.L. Sadik ${ }^{1}$ \\ ${ }^{1}$ College of Agriculture, University of Al-Anbar, Al-Anbar \\ ${ }^{2}$ Faculty of Agricultural Sciences, University of Sulaimani, Al-Sulaimania, Iraq
}

(Received December 11, 2016; Accepted January 10, 2017)

\begin{abstract}
This study was designed to investigate the effect of different ways of barley germination including natural, barley sprout powder and hydroponic planting in university of Sulaimani/ Faculty of Agricultural Sciences/ Fisheries lab. on some blood parameters of common carp Cyprinus carpio L. The study was conducted for 56 days and a total of 175 fingerlings common carp with mean initial weight was $34.71 \pm 4.59 \mathrm{gm}$. Seven experimental diets were fed with the control as $0 \%$ (T1), Hydroponic Planting 2.5 and $5 \mathrm{gm} / \mathrm{kg}$ diet (T2 and T3), Barley sprout powder BSP (2.5 and $5 \mathrm{gm} / \mathrm{kg}$ ) (T4 and T5), Natural planting (2.5 and $5 \mathrm{gm} / \mathrm{kg}$ ) (T6 and T7). According to the results significant differences observed among the treatments when compare with the control in RBC counts, $\mathrm{Hb}$ and PCV. In general BSP $(5 \mathrm{gm} / \mathrm{kg}$ diet $)$ was higher numerically than other treatments, especially when compared with control and hydroponic planting in both levels. No significant differences noticed in both of WBC counts and the counts of each of Monocytes, numerically, Barley sprout powder in both levels were more effects on WBC counts while T2 Hydroponic Planting $2.5 \mathrm{gm} / \mathrm{kg}$ diet was higher numerically in monocytes, T6 natural planting in Eosinophils and Basophils without significance. The statistical analysis of the Lymphocyte data showed no significance in Heterophil all the treatments were significantly differ than $\mathrm{T} 7$ natural planting $5 \mathrm{gm} / \mathrm{kg}$ diet.
\end{abstract}

Keywords: Natural planting, hydroponic germination, Barley sprout powder, Barley, common carp, blood indices Available online at http://www.vetmedmosul.org/ijvs

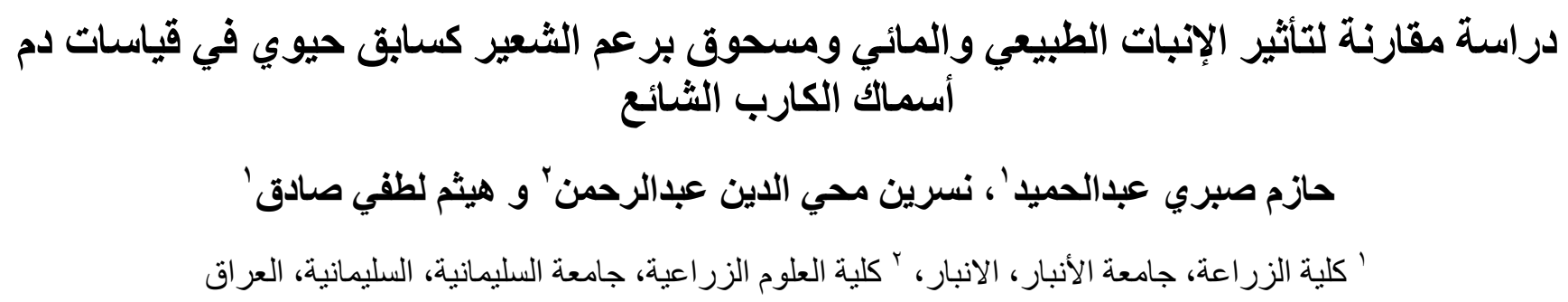

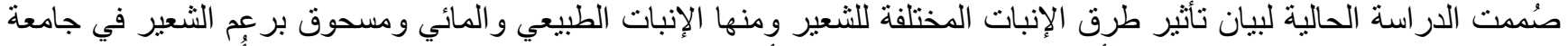

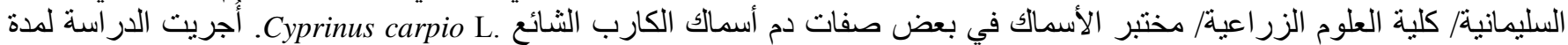

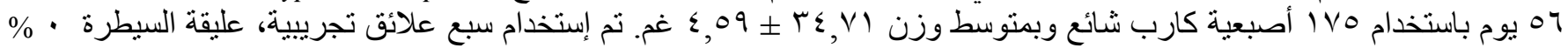

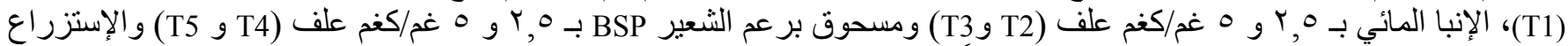

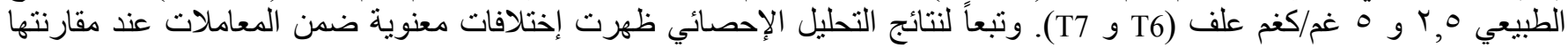



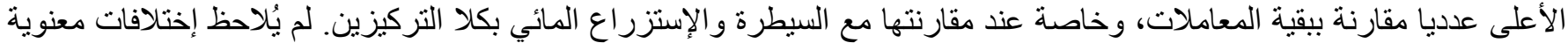

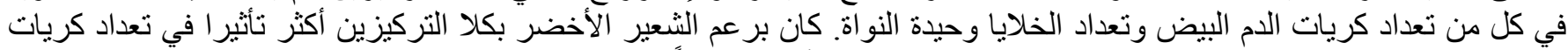

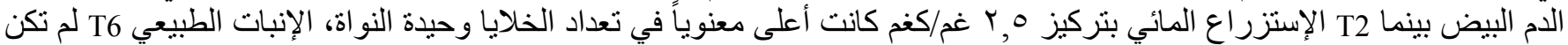




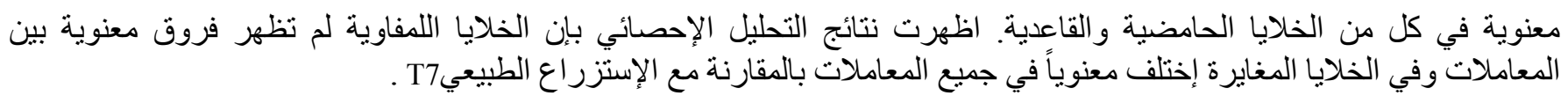

\section{Introduction}

World aquaculture has grown tremendously during the last years becoming an economically important industry. Today it is the fastest growing food-producing sector in the world with the greatest potential to meet the growing demand for aquatic food (1). Globally, aquaculture is expanding into new directions, intensifying and diversifying. A persistent goal of global aquaculture is to maximize the efficiency of production to optimize profitability. There are several food mainly carbohydrates use as prebiotic nowadays, but for a food can be classified as a probiotic, must have some characteristics. In different studies since 1999, many substances have been investigated as prebiotic. The most viable option appears to be the exploitation of low costly energy source, which abound in the sub tropics, such as cereal grains serve as inexpensive sources of carbohydrates for warm-water fish (2). Based on the study of (3), and (4), any foodstuff that reaches the colon, e.g. non-digestible carbohydrates, some peptides and proteins, as well as certain lipids, is a candidate prebiotic. Certain non-digestible carbohydrates seem authentic prebiotics. In aquaculture, few reports are available on the influence of prebiotics on growth and intestinal microflora in fish. In the earliest of studies with fish, certain nutrients such as linoleic acid, linolenic acid and soluble carbohydrate were investigated mainly by Ringo and his colleagues their effects on the aerobic/facultative anaerobic intestinal microbiota of Arctic char Salvelinus alpines (5). Barley is used for a wide range of traditional and novel enduses. In most countries, the major portion of barley is fed to

The purpose of the present study compare the effect of different sources of prebiotic from germinated barley; hydroponic (were planted in fisheries laboratories), Barley sprout powder from Changsha Huir Biological Tech co., LTD and natural planting planted in were planted in faculty of Agricultural sciences laboratories on some common carp blood indices.

\section{Materials and methods}

The experiment was conducted in the fish laboratory of Animal Production Department, Faculty of Agricultural Sciences of Sulaimani University, Sulaimani, Iraq.

\section{Experimental diet}

Seven practical diets were formulated based on the proximate composition of the feed ingredients. The ingredients were mixed with water to obtain dough. Then, the dough was passed through an electrical mincer for animals, particularly cattle and pigs. Human food uses of barley are more limited, although recent trends in the use of barley varieties, high in dietary fiber, have been identified. A significant high-value use is to produce malt as a raw material for the brewing industries, including beer and whiskey. An arabinoxylan-rich germinated barley product has been reported by (6) to induce the proliferation of bifidobacteria in the human intestine. However, as for all known and emerging prebiotics, convincing evidence of a consistent clinical benefit in the treatment of IBD remains to be demonstrated in large, randomised, double-blind, placebo-controlled studies (7). A recent review updated the concept of prebiotics and suggested that other components suitable for inclusion in the diet may exert specific effects upon gut bacteria, these were germinated barley foodstuffs, oligodextrans, gluconic acid, gentiooligosaccharides, pectic-oligosaccharides, mannan oligosaccharides, lactose, glutamine and hemicellulose rich substrates, resistant starch and its.derivatives, oligosaccharides from melibiose, lactoferrin-derived peptides and N-acetylchitooligosaccharides (4). Oats, barley, and rye are examples of cereals that contain a relatively high percent $(5-25 \%$ of total carbohydrates) of non-starch polysaccharides in the flour. The pentosan fraction of cereals is a complex mixture of branched polysaccharides with an arabinoxylan backbone containing small amounts of glucose and ferulic acid (8). Inulin is found naturally in a variety of plant foods such as bananas, barley, chicory, garlic, Jerusalem artichoke, leeks, onions and wheat and its use in endothermic animals is well documented in several comprehensive reviews (9).

pelleting by using Kenwood Multi-processors. The pellets were dried at room temperature for a few days and crushed to yield fine particles. Diet 1 (Control diet free of any barley), diets 2, 3, 4, 5, 6 and 7 contained 2.5 and $5 \mathrm{gm} / \mathrm{kg}$ diet of each of hydroponic, barley sprout powder and natural planting respectively on an equivalent protein basis. Composition and proximate analysis of different experimental diets were shown in table 1 and the chemical composition of the different diet by $(10,11)$ explained in table 2 .

\section{Fish and feeding regime}

Common carp fingerlings with an average weight $34.71 \pm 4.59 \mathrm{gm}$ were brought from local fish farms located in Daqoq/ HaftaGar Middle of Iraq were randomly allocated on the glass aquaria (7 fish /aquarium). Each treatment was represented in three aquariums (3 replicates). A feeding regime of $3 \%$ body weight per day was employed throughout the experiment for 56 days. Fish were 
individually weighed bimonthly. The feeding amount was then recalculated according to new weights. The fish were acclimated to laboratory conditions and fed with control pellets (30\% crude protein) prior to the feeding trial for 21 days.

\section{Experimental system}

The experimental facility consisted of 21 Aquaria $(60 \times 30 \times 30 \mathrm{~cm} ; 50$ litters each). Each aquarium was supplied with aerated and dechlorinated tap water, which was stored in tanks for 24 hours and aerated by air pump (Model-Rina 301) during the experimental period. The water level was maintained to a fixed level by the addition of new well-aerated fresh water and $30 \%$ of water was changed daily.

\section{Blood sampling}

At the end of the experimental period, three fish were randomly taken from each experimental group. All fish samples were weighed individually. The blood samples from each fish of the different groups were collected by suction of the caudal peduncle. Whole blood samples were collected in small plastic vials containing heparin for determination of hemoglobin ( $\mathrm{Hb})$. The hemoglobin (\%) concentrations were determined by using the hematology analyzer BC-2800 is a compact, fully automatic hematology analyzer with 19 parameters for complete blood count (CBC) test.

RBC (Red Blood Cell; $10^{12}$ cells/1); WBC (White Blood Cell; $10^{9}$ cells/l); Hb (Hemoglobin; g/l); MCH (Mean Corpuscular Hemoglobin; pg); MCHC (Mean Corpuscular Hemoglobin Concentration; g/l); MCV (Mean Corpuscular Volume; fl); Monocytes \%, Eosinophil\%, Basophils \%, Lymphocyte $\%$ and $\mathrm{H} / \mathrm{L}$ Ratio.

\section{Statistical analysis of data}

Statistical analysis was performed using the Analysis of variance (ANOVA) two-way classification and Fisher (LSD) multiple Range Test, to determine differences between treatments means at significance rate of $\mathrm{P}<0.05$. The standard errors of treatment means were also estimated. All statistics were carried out using Statistical Analysis System (SAS) program (SAS, 2000).

Table 1: Chemical Composition of fish diets used in the experiment according to $(10,11)$

\begin{tabular}{lc}
\hline Chemical Composition & \\
\hline Crude protein \% & 27.351 \\
Crude fat \% & 2.584 \\
Crude fiber \% & 6.155 \\
Energy KGal/ kg & 2235.2 \\
Ash \% & 87.61 \\
\hline
\end{tabular}

Table 2: Chemical composition of the different diet by $(10,11)$

\begin{tabular}{lcccccc}
\hline Ingredients & Crude protein \% & Crude fat \% & Dry materials\% & Crude fiber\% & Energy KG/Kg $\%$ in diet \\
\hline Animal protein concentrate & 40 & 5 & 92.9 & 2.2 & 2107 & 10 \\
Yellow corn & 8.5 & 3.6 & 89 & 2.2 & 3350 & 15 \\
Soybean meal & 44 & 1.1 & 89 & 7 & 2230 & 40 \\
Barely & 11 & 1.9 & 89 & 5.5 & 2640 & 15 \\
Wheat bran & 15.7 & 4 & 89 & 11 & 1300 & 18 \\
Premix & --- & --- & --- & --- & -- & 2 \\
\hline
\end{tabular}

Premix: vitamins: Vit. A: 6000 U.I; Vit. D3: 1000 U.I; Vit. E: 60 U.I.; Vit. K: 12 U.I.; Vit. B1: 24 mg/kg: Vit. B2:

$24 \mathrm{mg} / \mathrm{kg}$; Pantothenic acid: $60 \mathrm{mg} / \mathrm{kg}$; Niacin: 120mg/kg; Vit. B6: $24 \mathrm{mg} / \mathrm{kg}$; Biotin: $0.24 \mathrm{mg} / \mathrm{kg}$; Folic acid: 6mg/kg;

Choline chloride: $540 \mathrm{mg} / \mathrm{kg}$; Vit. B12:0.024 mg/kg.

Minerals include (mg/kg): Fe: 50; Cu; 3: Mn; 20; Zn; 50; I: 0.1; Co: 0.01; Se: 0.1

Animal concentrate commercial Brocon -5 Special W $40 \%$ imported by Wafi. B.V. Holland

\section{Results and discussion}

C. carpio is fresh water fish that is distinct to the Northern Hemisphere. This species requires an optimal temperature range between $20-28^{\circ} \mathrm{C}$ according to (12). The activity of the carps is affected by low water temperatures which minimize their moving and feeding activities (13). The temperature of water demonstrated in the present study was approximately $20^{\circ} \mathrm{C}, \mathrm{pH} 7.85$ and $\mathrm{DO}$ was (4.3-6.8) $\mathrm{mg} / \mathrm{L}$ throughout the entire experimental period. Over the entire period of the experiment, no mortalities among the fish have been observed. Wang et al., (14) and AlJammoor, (15) obtained a similar survival rate with $C$. carpio over 56 days of a feeding trial.

According to the results in table (3) a significant differences observed among the treatments than the control in $\mathrm{RBC}$ counts, $\mathrm{Hb}$ and PCV. In general Barley sprout powder $(5 \mathrm{~g} / \mathrm{kg}$ diet $)$ was higher numerically than other treatments, especially if compared with control and hydroponic planting in both levels. 
The hematological parameters of fish are reported to be affected by a range of factors, which include species, size, age, physiological status, environmental conditions and dietary regime, for example quality and quantity of feed, dietary ingredients, protein sources, vitamins, probiotics (16). Results show that there are slight increases in the values of hematological parameters of the common carp fed with all barely treatment in different sources compared to that fed with control feed. However, the hematological values obtained were within acceptable limits for carp, according to (17) and (18). These result were also in agreement with the reported by (2) of blood parameters in freshwater fish. $\mathrm{Hb}$ multiplicity may reduce the chances of $\mathrm{Hb}$ crystallization within the red blood cell. Hemoglobin exists at the limit of its solubility in the red blood cell and deoxy-Hb is less soluble than the oxy form. As tropical fishes routinely experience pronounced hypoxia or even anoxia, deoxygenated red blood cells may run the risk of $\mathrm{Hb}$ crystallization. The presence of multiple $\mathrm{Hb}$ isoforms may reduce the chances of $\mathrm{Hb}$ crystallization without affecting red blood cell $\mathrm{Hb}$ concentration, or even increasing total $\mathrm{Hb}$ concentration. Whether a relationship exists between red blood cell $\mathrm{Hb}$ concentration and the number of $\mathrm{Hb}$ isoforms remains to be investigated (19) and this appear in the present results in which highest $\mathrm{Hb}$ appeared in highest RBC.An increase in oxygen-carrying capacity of the blood during exposure to elevated temperature is presumably beneficial for ensuring adequate oxygen delivery at a time when metabolic rate becomes elevated, and it has been proposed that changes in hemoglobin content of the blood may be more important than changes in $\mathrm{P}_{50}$ (The most commonly used parameter to describe $\mathrm{O} 2$ transport characteristics of whole blood is $\mathrm{P}_{50}$, which refers to the $\mathrm{P}_{\mathrm{O} 2}$ at which blood is $50 \%$ saturated with oxygen) in securing oxygen transport under a number of environmental conditions (19).

A desirable nutritional changes may be occurred during sprouting that were mainly due to the breakdown of complex compounds into a more simple form, transformation into essential constituents and breakdown of nutritionally undesirable constituents, sprouting of grains affected the enzyme activity, increased total protein and changes in amino acid profile, increased sugars, crude fiber, certain vitamins and minerals, but decreased starch and loss of total dry matter (20) There were some arguments about the sprouting grains for convenience of green forage production in hydroponics system to compensate the feed resources for animals $(21,22)$. No significant differences noticed in each of WBC counts and the counts of each of Monocytes, Eosinophils and the Basophils that is mean no significant effect of different source of barley have been observed from the results in table (4) but numerically Barley sprout powder in both level were more effects on WBC counts while T2 Hydroponic Planting $2.5 \mathrm{~g} / \mathrm{kg}$ diet was higher numerically in monocytes, T6 Natural planting in Eosinophils and Basophils.

Table 3: Effect of adding Natural planting, Barley sprout powder and hydroponic germination of Barley on some common carp blood parameters

\begin{tabular}{lccc}
\hline Treatment & $\mathrm{RBC}\left(10^{12}\right.$ cells/l) & $\mathrm{Hb}(\mathrm{g} / \mathrm{dl})$ & $\mathrm{PCV}$ \\
\hline T1 (control) & $2.075 \pm 0.024 \mathrm{c}$ & $9.000 \pm 0.000 \mathrm{~b}$ & $28.500 \pm 0.020 \mathrm{~b}$ \\
T2 Hydroponic Planting 2.5g/ kg diet & $2.125 \pm 0.045 \mathrm{bc}$ & $9.0 \pm 0.128 \mathrm{~b}$ & $30.500 \pm 0.063 \mathrm{ab}$ \\
T3 Hydroponic Planting 5g/ $\mathrm{kg}$ diet & $2.150 \pm 0.060 \mathrm{abc}$ & $9.75 \pm 0.129 \mathrm{ab}$ & $31.000 \pm 0.026 \mathrm{a}$ \\
T4 Barley sprout powder $2.5 \mathrm{~g} / \mathrm{kg}$ diet & $2.300 \pm 0.071 \mathrm{ab}$ & $10.5 \pm 0.095 \mathrm{ab}$ & $31.500 \pm 0.055 \mathrm{a}$ \\
T5 Barley sprout powder $5 \mathrm{~g} / \mathrm{kg}$ diet & $2.350 \pm 0.081 \mathrm{a}$ & $10.75 \pm 0.089 \mathrm{a}$ & $32.750 \pm 0.038 \mathrm{a}$ \\
T6 Natural planting 2.5gm/ kg diet & $2.300 \pm 0.079 \mathrm{ab}$ & $10.0 \pm 0.163 \mathrm{ab}$ & $30.750 \pm 0.081 \mathrm{ab}$ \\
T7 Natural planting 5gm/ kg diet & $2.275 \pm 0.055 \mathrm{abc}$ & $10.0 \pm 0.082 \mathrm{ab}$ & $31.500 \pm 0.041 \mathrm{a}$ \\
\hline
\end{tabular}

Mean values with different superscripts within a column differ significantly $(\mathrm{P} \leq 0.05)$.

Table 4: Effect of adding Natural planting, Barley sprout powder and hydroponic germination of Barley on some common carp on differentials WBC count

\begin{tabular}{lcccc}
\hline Treatment & WBC $\left(10^{9}\right.$ cells $\left./ \mathrm{l}\right)$ & Monocytes & Eosinophils & Basophils \\
\hline T1 (control) & $21.250 \pm 0.024 \mathrm{a}$ & $1.000 \pm 0.000 \mathrm{a}$ & $1.000 \pm 0.000 \mathrm{a}$ & $1.000 \pm 0.000 \mathrm{a}$ \\
T2 Hydroponic Planting $2.5 \mathrm{~g} / \mathrm{kg}$ diet & $21.500 \pm 0.027 \mathrm{a}$ & $1.500 \pm 0.385 \mathrm{a}$ & $1.000 \pm 0.000 \mathrm{a}$ & $1.000 \pm 0.000 \mathrm{a}$ \\
T3 Hydroponic Planting $5 \mathrm{~g} / \mathrm{kg}$ diet & $21.500 \pm 0.047 \mathrm{a}$ & $1.000 \pm 0.000 \mathrm{a}$ & $1.500 \pm 0.385 \mathrm{a}$ & $1.500 \pm 0.385 \mathrm{a}$ \\
T4 Barley sprout powder $2.5 \mathrm{~g} / \mathrm{kg}$ diet & $22.500 \pm 0.077 \mathrm{a}$ & $1.250 \pm 0.400 \mathrm{a}$ & $1.250 \pm 0.400 \mathrm{a}$ & $1.250 \pm 0.400 \mathrm{a}$ \\
T5 Barley sprout powder $5 \mathrm{~g} / \mathrm{kg}$ diet & $22.500 \pm 0.057 \mathrm{a}$ & $1.500 \pm 0.385 \mathrm{a}$ & $1.250 \pm 0.400 \mathrm{a}$ & $1.250 \pm 0.400 \mathrm{a}$ \\
T6 Natural planting $2.5 \mathrm{gm} / \mathrm{kg}$ diet & $22.000 \pm 0.052 \mathrm{a}$ & $1.250 \pm 0.400 \mathrm{a}$ & $1.500 \pm 0.385 \mathrm{a}$ & $1.000 \pm 0.000 \mathrm{a}$ \\
T7 Natural planting $5 \mathrm{gm} / \mathrm{kg}$ diet & $22.250 \pm 0.043 \mathrm{a}$ & $1.250 \pm 0.400 \mathrm{a}$ & $1.250 \pm 0.400 \mathrm{a}$ & $1.000 \pm 0.000 \mathrm{a}$ \\
\hline
\end{tabular}

Mean values with different superscripts within a column differ significantly $(\mathrm{P} \leq 0.05)$. 
The significant analysis of the Lymphocyte data shown no significance in table 5 , in Heterotroph all the treatments were significantly differ than T7 Natural planting $5 \mathrm{gm} / \mathrm{kg}$ diet. Control treatment was higher significantly than other treatments in $\mathrm{H} / \mathrm{L}$ ratio. According to literature review no nearby research could be obtained so no comparison with previous data could be done to more explain of the present results.

Table 5: Effect of adding Natural planting, Barley sprout powder and hydroponic germination of Barley on some common carp immunological indices

\begin{tabular}{llll}
\hline Treatment & Lymphocyte & Heterotroph & \multicolumn{1}{c}{ H/L Ratio } \\
\hline T1 (control) & $72.000 \pm 0.025 \mathrm{a}$ & $22.000 \pm 0.098 \mathrm{a}$ & $0.305 \pm 0.098 \mathrm{a}$ \\
T2 Hydroponic Planting $2.5 \mathrm{~g} / \mathrm{kg}$ diet & $70.750 \pm 0.029 \mathrm{a}$ & $20.750 \pm 0.099 \mathrm{ab}$ & $0.293 \pm 0.070 \mathrm{ab}$ \\
T3 Hydroponic Planting $5 \mathrm{~g} / \mathrm{kg}$ diet & $72.500 \pm 0.018 \mathrm{a}$ & $21.000 \pm 0.103 \mathrm{ab}$ & $0.289 \pm 0.089 \mathrm{ab}$ \\
T4 Barley sprout powder $2.5 \mathrm{~g} / \mathrm{kg}$ diet & $70.500 \pm 0.008 \mathrm{a}$ & $19.750 \pm 0.145 \mathrm{ab}$ & $0.280 \pm 0.141 \mathrm{ab}$ \\
T5 Barley sprout powder $5 \mathrm{~g} / \mathrm{kg}$ diet & $70.750 \pm 0.014 \mathrm{a}$ & $19.000 \pm 0.074 \mathrm{ab}$ & $0.268 \pm 0.061 \mathrm{~b}$ \\
T6 Natural planting $2.5 \mathrm{gm} / \mathrm{kg}$ diet & $72.250 \pm 0.024 \mathrm{a}$ & $20.000 \pm 0.115 \mathrm{ab}$ & $0.278 \pm 0.096 \mathrm{ab}$ \\
T7 Natural planting $5 \mathrm{gm} / \mathrm{kg}$ diet & $70.500 \pm 0.008 \mathrm{a}$ & $18.750 \pm 0.027 \mathrm{~b}$ & $0.266 \pm 0.023 \mathrm{~b}$ \\
\hline
\end{tabular}

Mean values with different superscripts within a column differ significantly $(\mathrm{P} \leq 0.05)$.

\section{References}

1. FAO. The State of World Fisheries and Aquaculture. Opportunities and challenges. Food Agricul Organiz Uni Nation, Rome. 2014;pp:243.

2. Ighwela KA, Ahmad AB, Abol-Munafi AB. Hematological Changes in Nile Tilapia (Oreochromis niloticus)Fed with Varying Dietary Maltose Levels. World J Fish Marine Sci. 2012;4(4):376-381.

3. Mahious AS, Ollevier F. Probiotics and prebiotics in aquaculture: review, In: 1st Regional workshop on tech- niques for enrichment of live food for use in larviculture AAARC, Urmia. 2006:17-26.

4. Gibson GR, Probert HM, Van Loo Rastall RA, Roberfroid MB. Dietary modulation of the human colonic microbiota: updating the concept of prebiotics. The Authors, Nutrition Res Rev. 2004;17:259275.

5. Ringo E, Olsen RE. The effect of diet on aerobic bacterial flora associated with intestine of arctic charr (Salvelinus alpinus L.), J Appl Microbio. 1999;86:22-28.

6. Kanauchi O, Fujiyama Y, Mitsuyama K, Bamba T. Increased growth of Bifidobacterium and Eubacterium by germinated barley foodstuff, accompanied by enhanced butyrate production in healthy volunteers. Inter J Mole Med. 1990;3(2):175-179.

7. Gibson GR, Rastall RA. Prebiotics: Development \& Application. John Wiley \& Sons Ltd, the Atrium, Southern Gate, Chichester, West Sussex PO19 8SQ, England. 2006.

8. Damosaran S, Parkin KL, Fennema OR. Fennema's Food Chemistry, 4th Ed. 2008, 179-260. CRC Press, Boca Raton, FL Wang Y. Prebiotics: present and future in food science and technology. Food Res Inter. 2009;42:8-12.

9. NRC. Nutrient Requirements of Fish. National Acad. Press, Washington, DC. 1993:pp.114.

10. NRC. National Academy of Science, Nutrient requirement of poultry $9^{\text {th }}$ ed., Washington, USA., 1994:pp.157.

11. Horva'th L, Tama's G, Seagrave C. Carp and Pond Fish Culture. Fishing News Books, Oxford. 1992:pp.158.

12. Bauer C, Schlott G. Reaction of common carp (Cyprinus carpio L.) to oxygen deficiency in winter as an example for the suitability of radio telemetry for monitoring the reaction of fish to stress factors in pond aquaculture. Aquacul Res. 2006;37:248-254.

13. Kuhlwein H, Merrifield DL, Rawling MD, Foey AD, Davies SJ. Effects of dietary $\beta-(1,3)(1,6)$-D-glucan supplementation on growth performance, intestinal morphology and haemato-immunological profile of mirror carp (Cyprinus carpio L.). J Anim Physiol Anim Nutr. 2014;98:279-289.

14. Wang Y, Xu ZR. Effect of probiotics for common carp (Cyprinus carpio) based on growth performance and digestive enzyme activities. Ani Feed Sci Technol. 2006;127:283-292.

15. Al-Jammoor KMS. Evaluating the effects of dietary immunostimulants on growth performance, survival, immune response and digestive enzymes activity of Koi (Cyprinus carpio, Linnaeus 1758), M.Sc. thesis, University Perth, 2012.

16. Osuigwe DI, Obiekezie AI, Onuoha GC. Some haematological changes in hybrid catfish (Heterobranchus longifilis $x$ Clarias gariepinus) fed different dietary levels of raw and boiled jackbean (Canavalia ensiformis) seed meal. Afr J Biotechnol. 2005;4:10171021.

17. Badawi HK, Said MM. A Comparative Study of the Blood of Four Tulip Species (Pisces). Marine Biol. 1971;8:202-204.

18. Joshi PK, Bose M, Harish D. Changes in certain haematological parameters in a siluroid catfish Clarias batrachus (Linn) exposed to cadmium chloride. Pollu Res. 2002;21(2):119-131.

19. Val AL, De Almeida-Val VM, Randall DJ. The Physiology of Tropical Fishes. Volume 21 in the Fish Physiology Series. Edited by William S. Hoar, David J. Randall, and Anthony P. Farrell, Elsevier Inc. 2006.

20. Chavan J, Kadam SS. Nutritional improvement of cereals by sprouting. Crit Rev Food Sci Nutrit. 1989;28(5):401-437.

21. Tudor G, Darcy T, Smith P, Shallcross F. The intake and live weight change of drought master steers fed hydroponically grown, young sprouted barley fodder, Department of Agriculture Western Australia. 2003.

22. Fazaeli H, Golmohammadi HA, Tabatabayee SN, Asghari-Tabrizi M. Productivity and Nutritive Value of Barley Green Fodder Yield in Hydroponic System. World Appl Sci J. 2012;16(4):531-539. 